Article

\title{
The influence of the carbon equivalent on the weldability of high-strength low-alloy steel in the water environment
}

\author{
Jacek Tomków ${ }^{1, *}$, Michalina Tomków ${ }^{2}$ \\ ${ }^{1}$ Gdańsk University of Technology, Poland; \\ 2 University of Gdansk, Poland \\ Michalina Tomków; tomkow.michalina@gmail.com; \\ *Correspondence: Jacek Tomków Ph.D., jacek.tomkow@pg.edu.pl; \\ Received: 07.03.2019; Accepted: 09.04.2019
}

\begin{abstract}
From many years, the high strength low alloy steels are often used for offshore constructions. This constructions, due to the environment in which they work, require more frequent repairs than the constructions from the land. For economic reasons, repairs take place in the underwater conditions, however water significantly decreases the weldability of steel. The paper presents the results of the CTS weldability test for S460ML and S460 steels, which have a similar value of the yield point, but different carbon equivalent (Семгs) values. The welded joints were cut into specimens, which were then subjected to Vickers HV10 hardness measurements. The experiment has shown that as the CемIs value increases, the hardness in the heat affected zone (HAZ) of joints and in the weld metal increases.
\end{abstract}

Keywords: underwater welding; weldability; covered electrodes; carbon equivalent; hardness measurements;

\section{Introduction}

From year to year, steels with increased durability find increasing use on structural elements, with particular emphasis on offshore structures [1,2]. The use of this type of steel brings benefits in reducing the thickness and weight of components, reducing welding costs and increasing their mechanical properties [3,4]. Structures working in the water environment may require repair processes, which for economic reasons usually take place under the surface of the water. The most common method for this process is the variation of underwater welding with covered electrodes, during which the resulting joint, welding arc and diver are not separated from the surrounding environment $[5 \div 8]$. The wet welding scheme with covered electrodes is presented in figure 1.

Despite the widespread use, wet welding using covered electrodes continues to cause many problems, among which the most serious is considered: porosity of welds, heterogeneity of chemical composition of welds, or tendency to create cracks $[7,10]$.

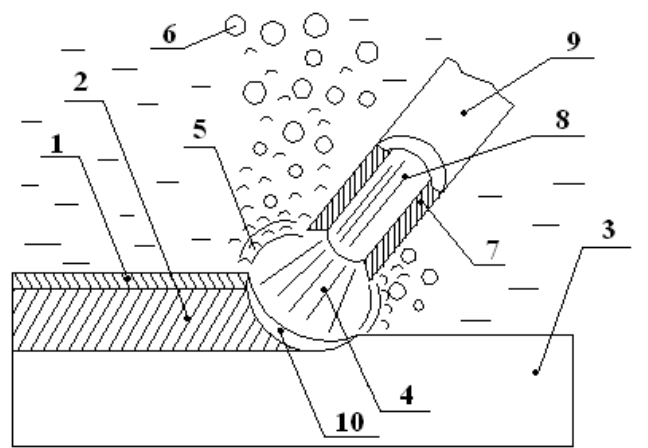

Fig. 1. Schematic diagram of underwater wet welding by coated electrodes: 1 - slag, 2 - weld, 3 - base material, 4 - electric arc, 5 - water vapor, 6 - gas bubbles, 7 - flux coating, 8 - core wire, 9 - consumable electrode, 10 - weld pool [9]

Among the reasons that intensify the deterioration of the quality of the joint can be distinguished $[11 \div 14]$ :

- instability of the arc glow;

- impaired visibility, making it difficult for the welder to observe the joint area; 
- increased content of diffusible hydrogen in the weld metal due to the influence of the welding environment;

- high pressure value caused by the depth of the process being carried out, which impairs the stability of the arc and influences metallurgical changes in the weld pool;

- intensified cooling rate of the joint, which significantly reduces the time t8/5, which in turn causes the formation of unfavorable structures;

- the presence of stresses resulting from the cooling rate and the presence of diffusible hydrogen in the weld metal.

While the weldability of high strength steels is well known in the field of conducting the process in the air, the research aimed at investigating the phenomenon in the aquatic environment is underway. Previous studies $[1 \div 9,15,16]$ show that materials from this group are most often characterized by bad weldability. However, there is no correlation study between the size of the carbon steel equivalent and the hardness and tendency to cold crack during wet welding with covered electrodes.

The aim of the experiments was to assess the effect of carbon equivalent on the weldability of steel with increased strength in the water environment during wet welding with covered electrodes. Three CTS samples were made of S460ML and S460N steel, which were then cut and subjected to Vickers HV10 hardness measurements.

\section{Materials used}

The study used fine-grained steels with increased durability of S460ML and S460N with a thickness of $12 \mathrm{~mm}$. The selection of these two steels was determined by the fact that they have a similar value of the yield point at different Cемгs values. The chemical composition was analyzed by emission spectroscopy with spark excitation, and the test results are presented in table I. Table II presents selected mechanical properties of the tested steel. The test was carried out at a depth of $150 \mathrm{~mm}$ in a freshwater environment at a temperature of about $20^{\circ} \mathrm{C}$.

Table I. Chemical composition of S460ML and S460N steel, \% wt.

\section{Content of the element, $\%$}

\begin{tabular}{cccccccccccc} 
Material & $\mathbf{C}$ & $\mathbf{S i}$ & $\mathbf{M n}$ & $\mathbf{P}$ & $\mathbf{C r}$ & $\mathbf{M o}$ & $\mathbf{N i}$ & $\mathbf{S}$ & $\mathbf{C u}$ & $\mathbf{V}$ & Ceмis* $^{*}$ \\
\hline S460ML & 0.12 & 0.50 & 1.40 & 0.015 & 0.04 & 0.01 & 0.03 & 0.004 & 0.001 & 0.010 & 0.365 \\
S460N & 0.16 & 0.53 & 1.51 & 0.02 & 0.07 & 0.03 & 0.05 & 0.007 & 0.13 & 0.097 & 0.464 \\
\hline
\end{tabular}

${ }^{*}$ Cemis $=\mathrm{C}+(\mathrm{Cr}+\mathrm{Mo}+\mathrm{V}) / 5+(\mathrm{Cu}+\mathrm{Ni}) / 15$

As an additional material, rutile covered electrodes E $380 \mathrm{R} 11$ with a diameter of $4.0 \mathrm{~mm}$ were chosen. The selection of electrodes was determined by the fact that they had to provide good metal properties of the weld metal and, in addition, should maintain the stability of the electric arc. The chemical composition and mechanical properties of the additive material are shown in table III.

Table II. Mechanical properties of S460ML and S460N steel, acc. to manufacturer data

\begin{tabular}{ccccc}
\hline Material & $\mathbf{R}_{\mathbf{e}}[\mathrm{MPa}]$ & $\mathbf{R}_{\mathrm{m}}[\mathbf{M P a}]$ & $\mathbf{A}[\%]$ & KV $_{-20}[\mathbf{J}]$ \\
\hline S460ML & 515 & 598 & 25 & 58 \\
S460N & 511 & 626 & 27,5 & 61 \\
\hline
\end{tabular}

Table III. Chemical composition (wt.\%) and mechanical properties of E $380 \mathrm{R} 11$ rutile electrodes [17]

\begin{tabular}{cccccc}
\hline \multicolumn{2}{c}{ Chemical composition [\% wt.] } & \multicolumn{4}{c}{ Mechanical properties } \\
$\mathbf{C}$ & $\mathbf{M n}$ & $\mathrm{Si}$ & $\mathbf{R e}_{\mathrm{e}}[\mathrm{MPa}]$ & $\mathbf{R}_{\mathrm{m}}[\mathrm{MPa}]$ & $\mathrm{A}_{5}[\%]$ \\
\hline 0.07 & 0.55 & 0.44 & 503 & 538 & 26 \\
\hline
\end{tabular}

The test plan assumed the performance of the CTS test in accordance with the guidelines contained in PN-EN ISO 17642-2:2005, according to which also appropriate non-destructive and destructive tests were carried out. Three samples were made for each of the analyzed plates, all DC (-), in accordance to the electrode manufacturer's recommendations. It was tried to ensure that the linear energy in the individual joints was on a similar level, however during the process, typical problems encountered under water, such as instability and migration of the electric arc, were encountered. For this reason, there are differences 
in energy, which was in the range of $0.82 \div 1.27 \mathrm{~kJ} / \mathrm{mm}$. The scheme of the CTS test is presented in figure 2, while the process parameters for individual samples are shown in table IV.

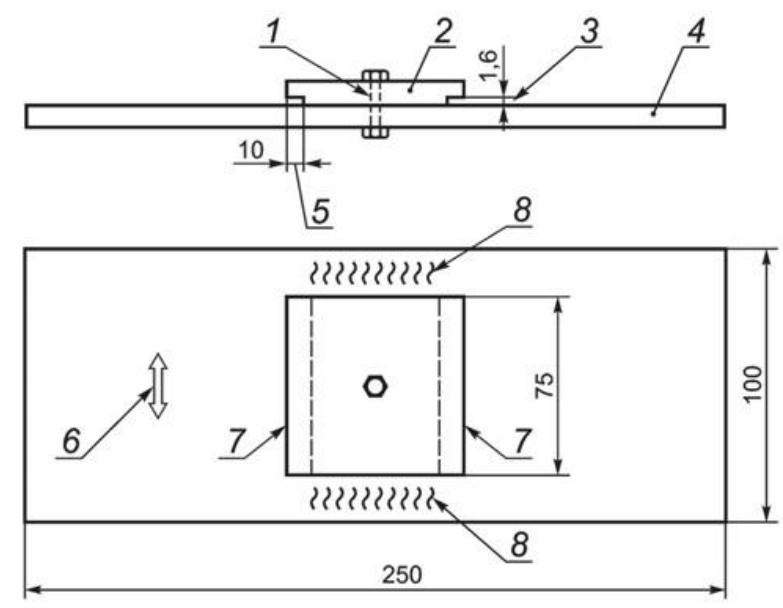

Fig 2. Schematic illustration of the CTS test specimen in accordance to PN-EN ISO 17642-2, 1 - Clarence hole $13 \mathrm{~mm}$ diameter, 2 - top plate, 3 - root notch gap, 4 - bottom plate, 5 - root notch depth, 6 - preferred principal rolling direction, 7 - test welds, 8 - anchor welds

Table IV. Welding conditions of CTS tests

\begin{tabular}{cccccccccc}
\hline \multirow{2}{*}{ Material } & $\begin{array}{c}\text { Sample } \\
\text { number }\end{array}$ & $\mathbf{I}[\mathbf{A}]$ & $\mathbf{U}[\mathbf{V}]$ & $\mathbf{t}[\mathbf{s}]$ & $\mathbf{q} \mathbf{1}[\mathbf{k J} / \mathbf{m m}]$ & $\mathbf{I}[\mathbf{A}]$ & $\mathbf{U}[\mathbf{V}]$ & $\mathbf{t}[\mathbf{s}]$ & $\mathbf{q 1}[\mathbf{k J} / \mathbf{m m}]$ \\
\hline \multirow{3}{*}{ S460ML } & $1 \mathrm{M}$ & 188 & 22.5 & 19.0 & 1.07 & 188 & 23.5 & 19.4 & 1.14 \\
& $2 \mathrm{M}$ & 184 & 25.0 & 20.7 & 1.27 & 188 & 23.8 & 18.5 & 1.10 \\
& $3 \mathrm{M}$ & 184 & 25.0 & 14.7 & 0.90 & 180 & 25.3 & 17.5 & 1.07 \\
& $4 \mathrm{~N}$ & 188 & 24.8 & 18.3 & 1.13 & 184 & 26.5 & 16.9 & 1.10 \\
S460N & $5 \mathrm{~N}$ & 188 & 24.0 & 18.0 & 1.08 & 184 & 26.0 & 12.8 & 0.82 \\
& $6 \mathrm{~N}$ & 188 & 23.5 & 16.9 & 0.96 & 184 & 24.8 & 17.9 & 1.09 \\
\hline
\end{tabular}

\section{Tests results}

\section{Non-destructive testing and macroscopic metallographic examination}

Non-destructive testing was the next step after making the samples. They were carried out in accordance with the recommendations of PN-EN ISO 17637:2017-02 (VT) and PN-EN ISO 3452-1:2013-08 (PT). As a result of these tests, the second weld N5, the first weld N6 and the first weld 3M were rejected. The next stage was macroscopic examination in accordance with PN-EN ISO 17639:2013-12. No inconsistencies were noted in any of the samples.

\section{Hardness measurements}

To compare the hardness, samples from different steels were selected from welds with a similar value of linear energy so as to minimize the effect of the difference in its value. Hardness was compared with each other:

- Pair I: welds of the first sample $1 \mathrm{M}$ (named 1M1) - ql $1.07 \mathrm{~kJ} / \mathrm{mm}$ with the first weld of the sample $5 \mathrm{~N}$ (5N1) - ql $1.08 \mathrm{~kJ} / \mathrm{mm}$;

- Pair II: welds of the second sample $1 \mathrm{M}(1 \mathrm{M} 2)-\mathrm{ql} 1.14 \mathrm{~kJ} / \mathrm{mm}$ with the first weld of the sample $4 \mathrm{~N}$ (4N1) - q1 $1.13 \mathrm{~kJ} / \mathrm{mm}$;

- Para III: welds of the second sample 2M (2M2) - ql $1.10 \mathrm{~kJ} / \mathrm{mm}$ with the second weld of the sample $4 \mathrm{~N}$ (4N2) - ql $1.10 \mathrm{~kJ} / \mathrm{mm}$;

- Para IV: welds of the second sample 3M (3M2) - ql $1.07 \mathrm{~kJ} / \mathrm{mm}$ with the second weld of the sample $6 \mathrm{~N}$ (6N2) - ql $1.09 \mathrm{~kJ} / \mathrm{mm}$.

Vickers HV10 measurements were carried out in accordance with the requirements of PN-EN ISO 9015-1:2011, in points according to the diagram presented in figure 3. The results of the measurements carried out are presented in the table V. 


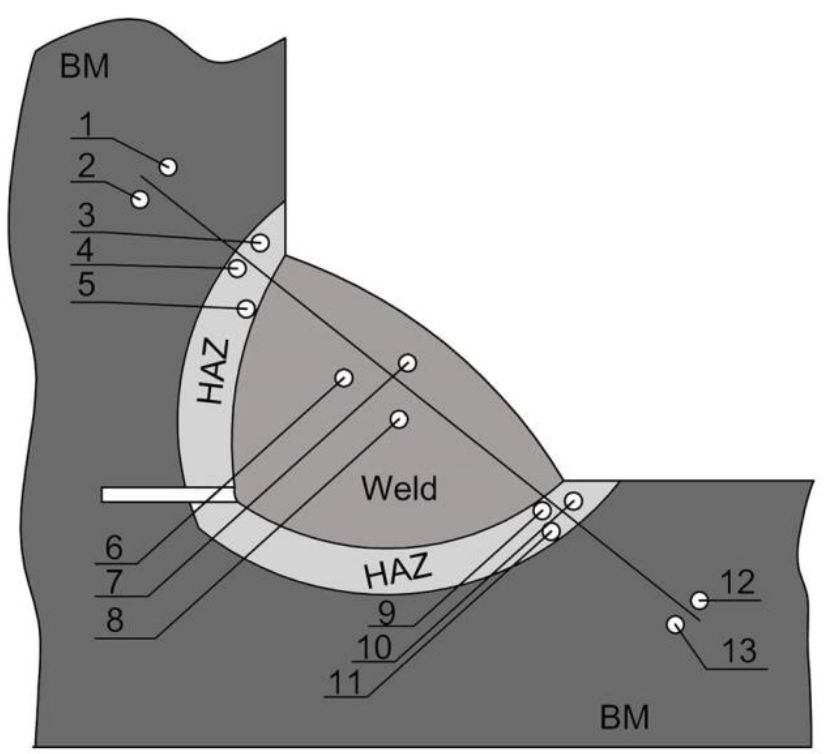

Fig. 3. Schematic layout of hardness measurement points distribution, BM - base material, HAZ - heat affected zone

Table V. Results of hardness measurements

\begin{tabular}{|c|c|c|c|c|c|c|c|c|c|c|c|c|c|c|c|}
\hline & Sample & & & & & HAZ & & & Weld & & & HAZ & & & \\
\hline \multirow{2}{*}{ Pair I } & $1 \mathrm{M} 1$ & 1.07 & 230 & 221 & 390 & 376 & 380 & 276 & 299 & 258 & 405 & 405 & 380 & 211 & 204 \\
\hline & $5 \mathrm{~N} 1$ & 1.08 & 209 & 211 & 441 & 525 & 488 & 297 & 294 & 306 & 503 & 508 & 508 & 195 & 199 \\
\hline \multirow{2}{*}{ Pair II } & $1 \mathrm{M} 2$ & 1.14 & 215 & 210 & 422 & 418 & 405 & 268 & 299 & 261 & 388 & 374 & 401 & 215 & 204 \\
\hline & $4 \mathrm{~N} 1$ & 1.13 & 212 & 209 & 464 & 425 & 459 & 282 & 290 & 299 & 493 & 488 & 498 & 201 & 203 \\
\hline \multirow[b]{2}{*}{ Pair III } & $2 \mathrm{M} 2$ & 1.10 & 215 & 215 & 419 & 439 & 424 & 278 & 261 & 288 & 428 & 416 & 399 & 217 & 227 \\
\hline & $4 \mathrm{~N} 2$ & 1.10 & 212 & 216 & 478 & 483 & 498 & 283 & 294 & 294 & 483 & 503 & 464 & 210 & 207 \\
\hline \multirow{2}{*}{ Pair IV } & $3 \mathrm{M} 2$ & 1.07 & 209 & 208 & 397 & 380 & 403 & 272 & 264 & 253 & 402 & 432 & 425 & 228 & 224 \\
\hline & $6 \mathrm{~N} 2$ & 1.09 & 207 & 213 & 488 & 488 & 508 & 304 & 304 & 299 & 503 & 518 & 498 & 212 & 209 \\
\hline
\end{tabular}

In each of the selected sample pairs, significantly higher hardness values in HAZ were noted for samples made of $S 460 \mathrm{~N}$ steel characterized by a higher value of carbon equivalent. As for weld metal, S460ML steel was characterized by lower hardness in this case, however, the differences were not as large as in the case of measurements placed in the HAZ. The distributions in individual pairs are presented in figures $4 \div 7$.

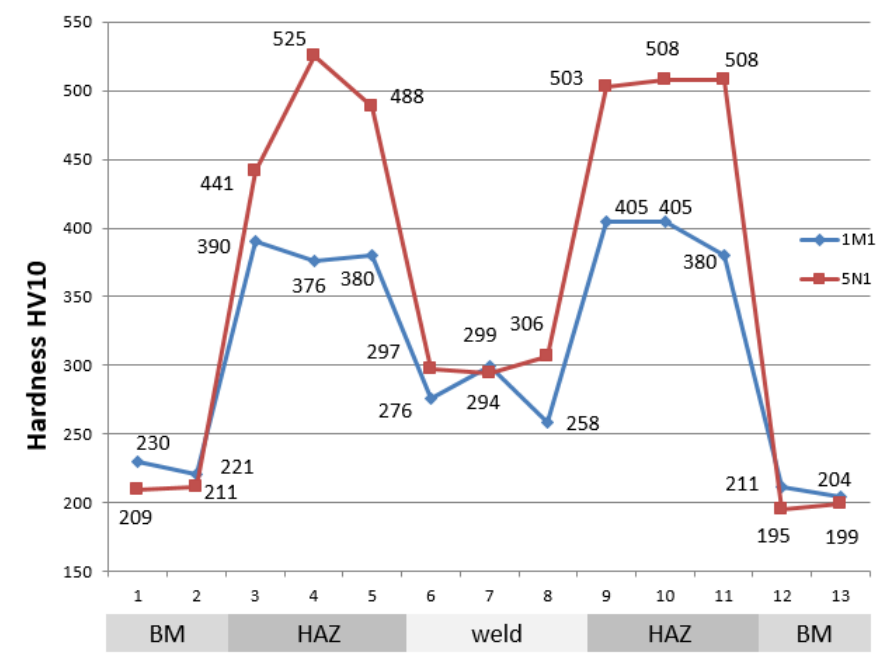

Fig. 4. Layout results of hardness tests in group I for specimens $1 \mathrm{M} 1$ and 5N1 


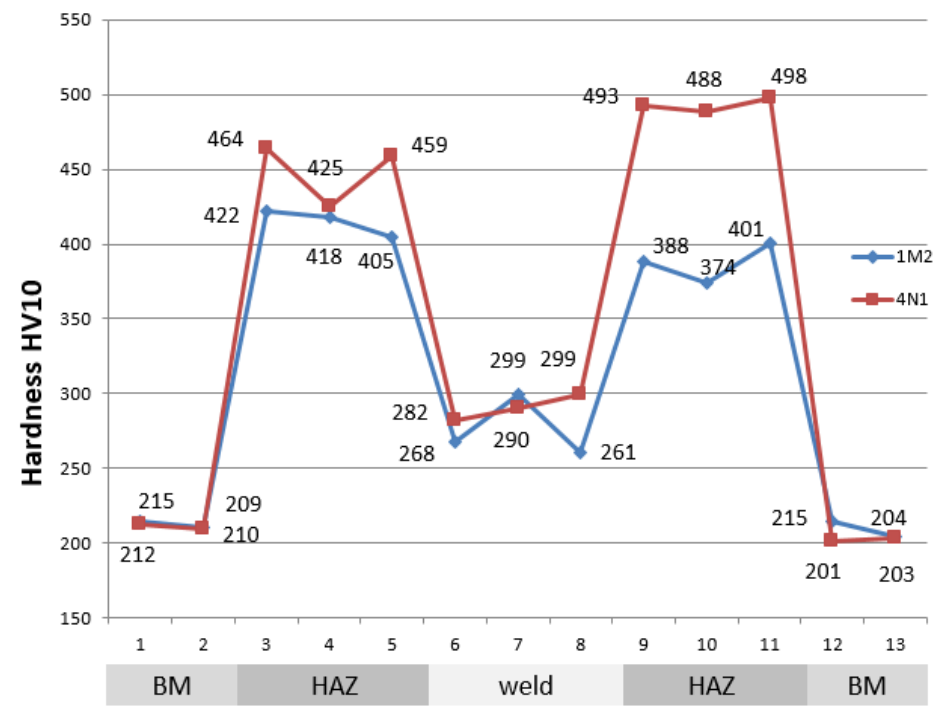

Fig. 5. Layout results of hardness tests in group II for specimens 1M2 and 4N1

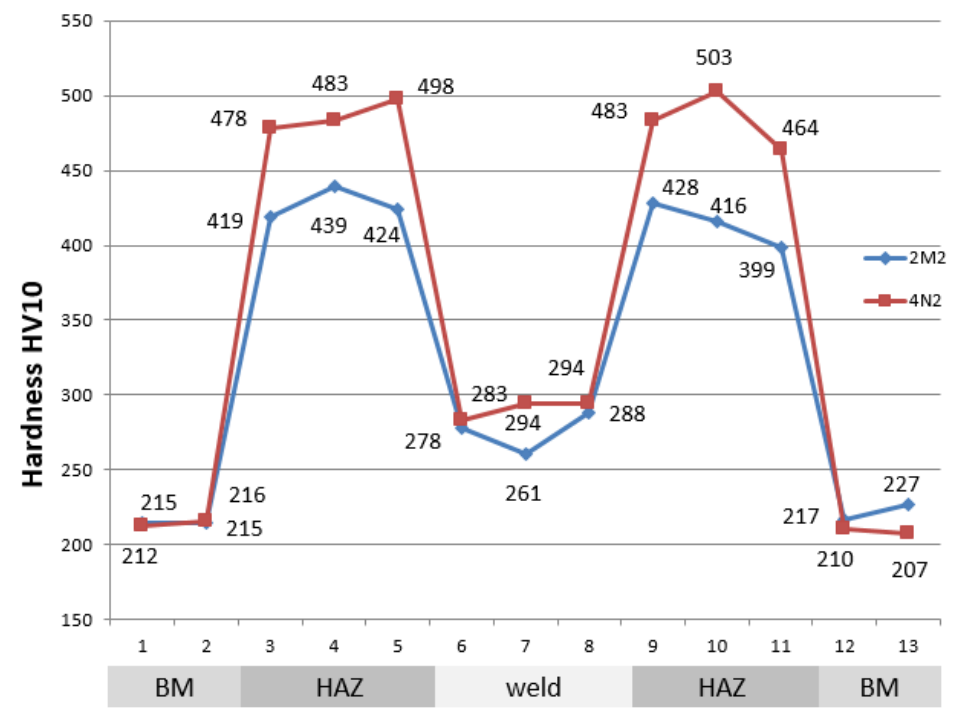

Fig. 6. Layout results of hardness tests in group III for specimens $2 \mathrm{M} 2$ and 4N2

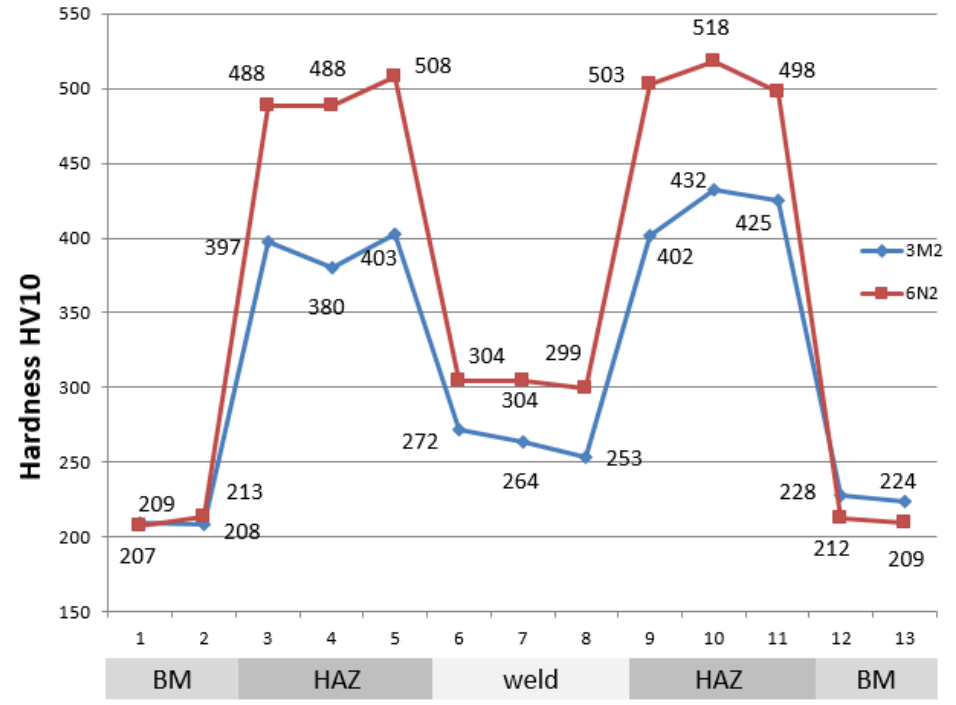

Fig. 7. Layout results of hardness tests in group IV for specimens 3M2 and 6N2 


\section{Summary and Conclusions}

The completed studies confirmed reports that the water environment makes it difficult to conduct the welding process [18]. During the samples, problems with the stability of the electric arc glow were encountered, which additionally deviated from the welding site. This contributed to changes in the amount of linear energy for individual welds. In addition, some of them were rejected at the stage of nondestructive and macroscopic tests. The samples were then selected to group into weld pairs of similar linear energy so as to be able to compare the hardness of individual zones in S460ML and S460 steel joints of similar Re size, and significantly different Cemis. Hardness distributions for individual samples showed that steel with a higher carbon equivalent is characterized by higher hardness both in the weld metal and in the heat affected zone, with differences in the HAZ being much greater.

As a result of the research, conclusions were formulated:

1. The water environment makes it difficult to conduct the welding process, clearly affecting the deterioration in the stability of the electric arc glow, which translates into a decrease in the quality of the joints.

2. CTS connectors made of $\mathrm{S} 460 \mathrm{~N}$ steel with $\mathrm{Ce}_{\mathrm{MIS}}=0.464 \%$ were characterized by higher Vickers HV10 hardness values than S460ML steel joints with $\mathrm{Ce}_{\mathrm{MIS}}=0.365 \%$. The phenomenon was observed both in the weld metal and HAZ tests of individual joints, which were welded with a similar value of linear energy.

3. The hardness of the S460N steel HAZ was up to $525 \mathrm{HV} 10$, which suggests that it can be characterized by a very high tendency to cold cracks under wet welding conditions with covered electrodes. In the case of S460ML steel, the maximum hardness was recorded at 439 HV10, which may also mean that there were cold cracks in the HAZ.

4. In the case of welding in an aqueous environment, the size of the carbon equivalent greater than the value of the yield point of the combined materials has a greater influence on the weldability of steel.

\section{Resources}

[1] Qiang X., F. Bijlaard F., Kolstein H. Elevated-temperature mechanical properties of high strength structural steel S460N: Experimental study and recommendations for fire-resistance design. Fire Safety Journal, 2013, Vol. 55, 1521. [CrossRef]

[2] Omajane J., Martikainen J., Kah P. Weldability of thermo-mechanically rolled steels used in oil and gas offshore structures. The International Journal of Engineering and Science, 2014, Vol. 3(5), 62-69. [Hyperlink]

[3] Skowrońska B., Szulc J., Chmielewski T., Sałaciński T., Swiercz R. Properties and microstructure of hybrid Plasma+MAG welded joints of thermomechanically treated S700MC steel. 27th Anniversary International Conference on Metallurgy and Materials (METAL) 2018, Brno, Czech Republic. [Google Scholar]

[4] Górka J. Assessment of steel subjected to thermomechanical control process with respect to weldability. Metals, 2018, Vol. 3(3), 169. [CrossRef]

[5] Tomków J., Janeczek A. The influence of welding environment on the properties of Tekken joints made from S355J2C+N steel. Welding Technology Review, 2019, Vol. 91(1), 15-19. [CrossRef]

[6] Tomków J., Łabanowski J., Fydrych D., Rogalski G. Cold cracking of S460N steel in water environment. Polish Maritime Research, 2018, Vol. 3(99), 131-136. [CrossRef]

[7] Tomków J., Rogalski G., Fydrych D., Łabanowski J. Improvement of S355G1+N steel weldability in water environment by Temper Bead Welding. Journal of Materials Processing Technology, 2018, Vol. 262, $372-381$. [CrossRef]

[8] Tomków J., Rogalski G., Fydrych D., Łabanowski J. Advantages of the application of the temper bead welding technique during wet welding. Metals, 2019, Vol. 12(6), 915. [CrossRef]

[9] Tomków J., Rogalski G., Fydrych D., Łabanowski J., Weldability testing of S460N steel in water environmental by using tekken. Welding Technology Review, 2018, Vol. 90(5), 41-45. [CrossRef]

[10] Padilla E., Chawla N., Silva L.F., dos Santos V.R., Paciornik S., Image analysis of cracks in the weld metal of a wet welded steel joint by threedimensional (3D) X-ray microtomography. Materials Characterization, 2013, Vol. 83, 139-144. [CrossRef]

[11] Guo N., Yang Z., Wang M., Yuan X., Feng J., Microstructure and mechanical properties of an underwater wet welded dissimilar ferritic/austenitic steel joint. Strength of Materials, 2018, Vol. 47(1), 12-18. [CrossRef]

[12] Schaupp T., Rhode M., Yahyaoui H., Kannengiesser T., Influence of heat control on hydrogen distribution in high-strength multi-layer welds with narrov groove. Welding in the World, 2018, 1-10. [CrossRef] 
[13] Wang J., Sun Q., Wu L., Liu L., Teng J., Feng J., Effect of ultrasonic vibration on microstructural evolution and mechanical properties of underwater wet welding joint. Journal of Materials Processing Technology, 2017, Vol. 246, 185-197. [CrossRef]

[14] Wang J., Sun Q., Zhang S., Wang C., Wu L., Feng J., Characterization of the underwater welding arc bubble through a visual sensing method. Journal of Materials Processing Technology, 2018, Vol. 251, 96-108. [CrossRef]

[15] Gao W.B., Wang D., Cheng F., Di X., Xu W., Mictostructural and mechanical performance of underwater wet welded S355 steel. Journal of Materials Processing Technolony, 2016, Vol. 238, 333-34. [CrossRef]

[16] Gao W.B., Wang D., Cheng D., Deng C., Xu W. Underwater wet welding for HSLA steels: chemical composition, defects, microstructures, and mechanical properties. Acta Metallurgica Sinica (English Letters), 2015, Vol. 9, 1097 1108. [CrossRef]

[17] Products catalog Omnia of Lincoln Electic.

[18] Fydrych D., Rogalski G., Łabanowski J., Problems of underwater welding of higher-strength low alloy steels. Institute of Welding Bulletin 2014, Vol. 5, 187-195.

(C) 2019 by the authors. Submitted for possible open access publication under the terms and conditions of the Creative Commons Attribution (CC BY) license (http://creativecommons.org/licenses/by/4.0/). 